\title{
Features of the Material Composition of the Main Oil and Gas Complex of the Shu-Sarysu Basin
}

\author{
Zh.S. Tulemissova ${ }^{1,2}$, V.V. Korobkin ${ }^{2}$ \\ ${ }^{1}$ Department of Geological Surveying, Prospecting and Exploration of Mineral Deposits, Satbayev University, \\ Satpayev Ave., 22 -050000, Almaty, Republic of Kazakhstan. \\ ${ }^{2}$ Department of Geology and Exploration, JSC «Kazakh-British Technical University, Tole bi St, 59 - 050000, \\ Almaty, Republic of Kazakhstan.
}

\begin{abstract}
:
The article deals with exploration of the features of the material composition of the main oil and gas complex of the Shu-Sarysu basin. In the process of studying the Carboniferous-Permian section, rock samples were taken from two lithologicstratigraphic sections of the Lower Carboniferous and Permian systems, from which the most representative rocks were selected, giving an idea of the material composition of the rocks of this stratigraphic section of the Shu-Sarysu depression. Further thermal and X-ray diffraction analyzes of these samples were carried out. Mineralogical interpretation of the analysis results showed the presence in the samples a number of formations, among which there are silicon oxides, feldspars, minerals of layered silicates, carbonates, etc. The method of localization of concentrated and dispersed forms of OM in the compositions of quartz formations is based on the laws of physical and ion sorption. Therefore, connection with the surface of crystals of other minerals is carried out mainly by means of underlying films made of secondary minerals of the group of phyllosilicates. The article proves that: 1) the packaging of $\mathrm{OM}$ in clay minerals takes place in the intergrid spaces of their layered structures or over the broken connections of the planes of the silicon-oxygen frame of montmorillonites and members of this series of minerals; 2) in limestones concentration of Corg takes place in micro pores, as well as in cracks and chips of monomineral forms of $\mathrm{CaCO} 3$; 3) the background content of the dispersed organic matter (DOM) in the Carboniferous-Permian section is uniformly distributed in the range $0.1-0.5 \%$; 4 ) in terrigenous rocks, in which feldspars and clay minerals predominate, the DOM content reaches $2 \%$; 5) the obtained data will be used to correct the forecast resources of the southwestern part of the ShuSarysu basin.
\end{abstract}

Keywords - Material Composition, Oil and Gas Complex, Shu-Sarysu Basin, Natural Resources.

\section{INTRODUCTION}

The Shu-Sarysu oil and gas basin is located within the boundaries of South Kazakhstan, and its forecast prospects for hydrocarbons are not fully understood. A number of medium and small gas and gas condensate fields are being developed on the area of this basin (Amangeldy, Pridorozhnoye, etc.) [1]. Three strata in the Upper Paleozoic section of the Shu-Sarysu basin are distinguished:lagoon-terrigenous-salt-bearing strata of the Famennian-lower tour, up to 800 meters thick; terrigenous-carbonate - marine, shallow, sometimes coalbearing, Lower Carboniferous system - 500-2000 meters; alluvial-lake, predominantly red, mid Carboniferous - Permian, up to 2.5 kilometers. At the base of the Lower Permian, the saltbearing strata is up to 500 meters [2-8].

\section{MATERIAL AND METHODS}

In the process of studying the Carboniferous-Permian section, rock samples were taken from two lithologic-stratigraphic sections. The first section, $5.5 \mathrm{~km}$ long, is located in the foothills of the Small Karatau ridge according to the Kyzylsai $\log$ (10 km south of Lake Bilikol).The second section, $35 \mathrm{~km}$ long, is a continuation of the previous one and is located on the traverse - the northern border of Lake Bilikol (Aksai GOK area)and further to the north-west towards to the Akkol settlement and the Talas River (Fig. 1).Thus, rock samples of the Lower Carboniferous and Permian system were taken, from which the most representative rocks were selected, giving an idea of the material composition of the rocks of this stratigraphic section of the Shu-Sarysu depression. Age and lithological types of rocks are given in Tables 1-3. Further thermal and X-ray diffraction analyzes of these samples were carried out. Mineralogical interpretation of the analysis results showed the presence in the samples a number of formations, among which there are silicon oxides, feldspars, minerals of layered silicates, carbonates, etc. 


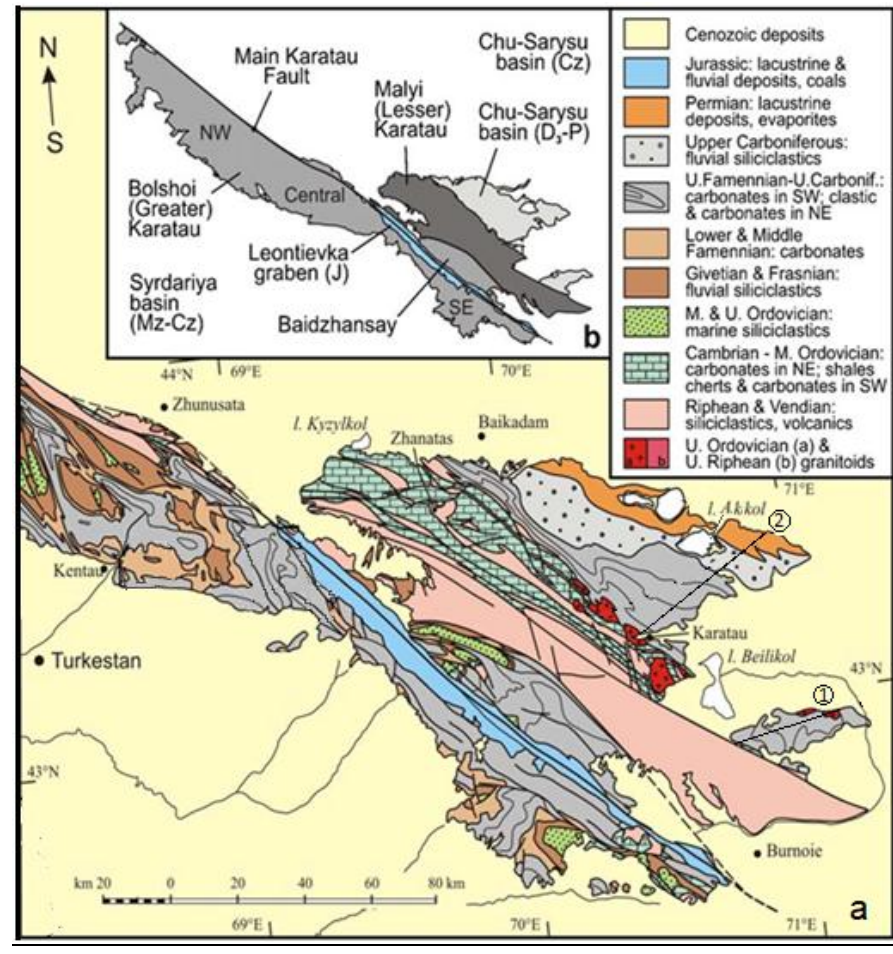

Fig. 1.Schemes of the geological structure (a) and tectonic zoning (b) of the Karatauridge and the south-western end of the Shu-Sarysu basin, as well as adjacent territories. Straight line segments and number in circles shows the position of the key sections

\section{RESULTS AND DISCUSSION}

In the first section, the quantitative ratios of the silicon oxides and hydroxides minerals and silicates were determined and clarified. Quartz and its modifications in the studied section are the most common, its presence is detected in all samples submitted for analysis. The content in the samples ranges from $5 \%$ to $98 \%$ (Tables 1-2).Quartz belongs to thermally amorphous formations, since, in the test temperature range, its presence can be determined only by a slight manifestation on the DTA-curve (differential thermal analysis) in the region of $500^{\circ} \mathrm{C}$.As a comparison, rocks containing more than $80 \%$ of quartz develop the same endothermic effect when heated as in the case of thermal dissociation of a two percent calcite sample.

At lower concentrations of crystalline silica in the samples, the indicated feature is lost against the thermal manifestations of other related minerals, which makes it difficult to determine the amount of this oxide. In this case, the content of the specified mineral in the composition of the sample was established during an additional surveying made on the basis of the heating of the prebaked sample, when thermally active substances adjacent to quartz had already decayed and can no longer serve as a hindrance in the search for the only effect of the polymorphic transition of $\mathrm{SiO}_{2}$ from the $\alpha$ state to the $\beta$ modification.
Amphibole, as silicate, which includes hydroxyl water (2.9\%) in its structure, usually presents, when heated $\left(400-650^{\circ} \mathrm{C}\right)$, a very poorly expressed endothermic manifestation associated with the release of the $\mathrm{OH}$ group into the atmosphere. Heating of the K-13-6.1 sample in the specified temperature range also leads to hydroxyl losses and causes curvature of the DTA and DTG lines (differential thermogravimetric analysis).In this case, the thermogravimetric curve captures $0.8 \%$ of the weight loss, of which half is the result of dehydroxylization of hydromica, and the rest $(\Delta \mathrm{m}=0.4 \%)$ accounts for the release of amphibole crystal water to the atmosphere. Water loss is $13.8 \%$, (Table 1).

Thermally inert minerals (TIM) - natural formations that are difficult to thermally diagnose. In our case, these are amorphous formations of quartz, plagioclase, orthoclase, etc. Their quantitative content in samples is usually determined by the residual principle. So, the total content of plagioclase ( $43 \%$ ), detected by X-ray analysis, is close to the results of thermal determinations of poorly informative TIM, which were detected by exclusion from samples of thermally diagnosed minerals (Table 1).

Mixed-layered minerals (MLM), chlorite and hydromica were found by thermal analysis in a number of samples (Table 1). MLM was detected in sample K-13-1, which gave endothermic reactions in the range of $20-230^{\circ} \mathrm{C}, 230-460^{\circ} \mathrm{C}$ and $460-600^{\circ} \mathrm{C}$, associated with the decomposition of its structure. The existence of MLM destruction processes in these temperature ranges indicates the presence of weak line dips on the conjugate segments of the differential thermogravimetric curve. This is also indicated by the development of two stages of mass change on the TG-curve caused by dehydration of the system $(\Delta \mathrm{m}=$ $\left.0.65 \% \mathrm{H}_{2} \mathrm{O}\right)$ and release of hydroxyl water into the atmosphere $(0.2 \%+0.5)$. The weight loss of the sample during these reactions amounted to $13.5 \%$ in total, which, taking into account the MLM stoichiometry, corresponds to $7.7 \%$ of this inclusion in the rock (Table 1).

Chlorite in the rock K-13-1, due to its low content in the sample, was calculated according to the residual principle. In the interval of $720-815^{\circ} \mathrm{C}$, the mineral loses $0.15 \%(\mathrm{OH})$ of its weight, which, taking into account its stoichiometric formula, is $1.25 \%$ of the mass of the sample. The structure of chlorite (sample K-13-4) has intercrystalline defects, which causes an excess of molecular water and leads to a decrease of the binding energy of the $\mathrm{OH}$ groups. This is also evidenced by the decrease (by $\sim 150^{\circ} \mathrm{C}$ ) of the temperature of release to the atmosphere of the hydroxyl part of water. The total weight loss during dehydration of this mineral in the process of its heating is $0.6 \%$ $\left(\mathrm{H}_{2} \mathrm{O}\right)+0.3 \%(\mathrm{OH})=0.9 \%$, which corresponds to the chlorite content in this sample equal to $3.9 \%$.

Hydromica (sample K-13-6.1) in the range of $60-100^{\circ} \mathrm{C}$ loses $0.4 \%$ of its weight $\left(\mathrm{H}_{2} \mathrm{O}\right)$, and in the range of $400-630^{\circ} \mathrm{C}$ takes out another $0.4 \%$ of its mass $(\mathrm{OH})$. According to stoichiometry of hydromica, these weight losses correspond to the presence in the sample of $\sim 5 \%$ of this mineral (Table 1 ). 
Table 1.Results of thermal analysis of carbonate-terrigenous rocks (biohermal construction) of the Lower Carboniferous, the Viseanstage of the southwestern part of the Shu-Sarysu depression (log Kyzylsai, south of Lake Bilikol - profile 1)

\begin{tabular}{|c|c|c|c|c|c|c|c|c|}
\hline \multirow[t]{2}{*}{$\begin{array}{l}\text { Lithology, age, } \\
\text { № sample }\end{array}$} & \multicolumn{3}{|c|}{$\begin{array}{c}\mathrm{CO}_{\text {org andsample mineral composition, }} \\
\% \text { by mass }\end{array}$} & \multicolumn{4}{|c|}{$\begin{array}{l}\text { Compounds carried from } \\
\text { minerals during their heating, } \% \\
\text { by mass }\end{array}$} & \multirow{2}{*}{ 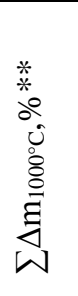 } \\
\hline & $\stackrel{N}{\stackrel{ \pm}{Z}}$ & $\frac{\mathscr{0}}{\frac{\pi}{\pi}}$ & Other minerals & $\overbrace{}^{\frac{0}{0}}$ & 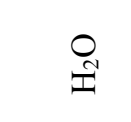 & $\bar{T}$ & ర & \\
\hline 1 & 2 & 3 & 4 & 5 & 6 & 7 & 8 & 9 \\
\hline $\begin{array}{l}\text { Gravelstone with silicon } \\
\text { and quartz pebbles, } \mathrm{C}_{1} \mathrm{v}, \\
\mathrm{K}-13-1\end{array}$ & $>40$ & 4.3 & $\begin{array}{l}\text { MLM-7.7; chlorite- } \\
1.25 ; \text { TIM }>4 \\
\text { (plagioclase etc.) }\end{array}$ & 0.3 & 0.65 & 0.85 & 1.9 & 3.7 \\
\hline 1 & 2 & 3 & 4 & 5 & 6 & 7 & 8 & 9 \\
\hline $\begin{array}{c}\text { Arcose sandstone, } \mathrm{C}_{1} \mathrm{v}, \mathrm{K}- \\
13-2\end{array}$ & $\sim 60$ & - & $\begin{array}{l}\text { TIM (thermally } \\
\text { amorpousSiO} \\
\text { ) } \sim 40\end{array}$ & 0.2 & - & 0.2 & - & 0.4 \\
\hline $\begin{array}{c}\text { Siliceouslimestone, } \mathrm{C}_{1} \mathrm{v}, \\
4-\mathrm{K}-13\end{array}$ & $\sim 10$ & 81.8 & $\begin{array}{l}\text { TIM<5; chlorite-3.9; } \\
\text { rhodochrosite- } 0.8\end{array}$ & 0.3 & 0.60 & 0.3 & 36.3 & 7.5 \\
\hline $\begin{array}{l}\text { Arcosesandstone, } \mathrm{C}_{1} \mathrm{v} \\
\mathrm{K}-13-6,1\end{array}$ & $\sim 80$ & - & $\begin{array}{l}\text { amphibole-13.8; } \\
\text { TIM>5; gypsum 1.4; } \\
\text { hydromica } 5\end{array}$ & 0.2 & 0.70 & 1.0 & - & 1.9 \\
\hline $\begin{array}{l}\text { Silicified wood, } C_{1} v, K- \\
13-6,2\end{array}$ & $\sim 98$ & - & - & 0.5 & $\begin{array}{c}\mathrm{H}_{2} \mathrm{O} \\
\left(\text { atm }^{*}\right)- \\
0.4\end{array}$ & 0.2 & - & 1.1 \\
\hline $\begin{array}{c}\text { Siliceouslimestone, } \mathrm{C}_{1} \mathrm{v}, \\
8-\mathrm{K}-13\end{array}$ & $\sim 10$ & 82.5 & TIM $>5$ & 0.5 & - & - & 39.3 & 39.8 \\
\hline $\begin{array}{l}\text { Limestone, } \mathrm{C}_{1 \mathrm{~V}} \\
\mathrm{~K}-13-10\end{array}$ & $<5$ & 95.0 & - & 0.4 & - & - & 41.8 & 42.2 \\
\hline $\begin{array}{l}\text { Siliceouslimestone, } \\
\mathrm{C}_{1 \mathrm{~V}}, \mathrm{~K}-13-11\end{array}$ & $>5$ & 93.0 & - & 0.4 & - & - & 40.8 & 41.2 \\
\hline $\begin{array}{l}\text { Siliceouslimestone, } \\
\mathrm{C}_{1 \mathrm{~V}}, \mathrm{~K}-13-13\end{array}$ & $>10$ & 88.0 & - & 0.5 & - & - & 38.7 & 9.2 \\
\hline $\begin{array}{c}\text { Siliceouslimestone, } \\
\mathrm{C}_{1 \mathrm{v}}, \mathrm{K}-13-14\end{array}$ & $\sim 40$ & 58.0 & rhodochrosite- 0.8 & 0.8 & $\begin{array}{c}\mathrm{H}_{2} \mathrm{O} \\
\left(\mathrm{atm}^{*}\right)- \\
0.5\end{array}$ & - & 25.5 & 26.8 \\
\hline $\begin{array}{l}\text { Silicified coral limestone, } \\
\mathrm{C}_{1} \mathrm{v}, \mathrm{K}-13-15\end{array}$ & $\sim 30$ & 66.8 & rhodochrosite-1.3 & 0.3 & - & - & 29.9 & 30.2 \\
\hline $\begin{array}{l}\text { Silicified coral limestone, } \\
\mathrm{C}_{1} \mathrm{v}, \mathrm{K}-13-16\end{array}$ & $>15$ & 81.6 & - & 0.3 & $\begin{array}{c}\mathrm{H}_{2} \mathrm{O} \\
\left(\mathrm{atm}^{*}\right)- \\
0.4\end{array}$ & - & 35.9 & 6.6 \\
\hline
\end{tabular}


Calcite is widely developed in rocks, rhodochrosite is found in association with it (less than $2 \%$ ). The calcite content in the samples (in 8 cases out of 12) varies within $58-95 \%$. Carbonates are distinguished by their perfect crystalline structure, as evidenced by the high temperature of dissociation of $\mathrm{CaCO}_{3}$, the limiting rate of emission of carbon dioxide into the atmosphere and the intense endothermic effect of mineral destruction.

During thermal decomposition, the above-listed minerals form a clear symmetry of the side lines of the DTA- and DTG-peaks, which is usually due to the absence of other calcite generation in the compositions of these formations or due to the high purity of $\mathrm{CaCO}_{3}$. Exceptions are the K-13-4 and K-13-15 samples, in which calcite is associated with a small amount of rhodochrosite ( 0.8 and $1.3 \%$, respectively).

Gypsum is found only in sample K-13-6.1. The presence of it in the sample was noted by all three curves, which reflected with their curvature within $80-280^{\circ} \mathrm{C}$ the processes of removal into the atmosphere of two differently connected forms of $\mathrm{H}_{2} \mathrm{O}$. The first phase of dehydration of this sulfate occurs before the formation of the hemihydrate $\left(150^{\circ} \mathrm{C}\right)$ with a weight loss of $0.2 \%$. The second stage of dehydration reduces the sample mass also by $0.2 \%$, after which the crystal lattice of the dehydrated product is rearranged into the anhydrite lattice. Thus, the amount of gypsum in the composition of the specified sample, according to the values of selected water when heated, is $1.4 \%$.

Organic matter (OM), according to DTA-determinations and thermogravimetric analysis, is present in small quantities in almost all samples of the rocks. As a thermally active substance, it always generates thermal energy in the range of $250-500^{\circ} \mathrm{C}$, which is fixed on the DTA-curve in the form of two stepped bends of exothermic orientation [9-12]. This property of the compound under consideration is the main indicator of agents that allowed it to be diagnosed. The thermogravimetric curves of the samples within the limits of the decomposition temperature of the $\mathrm{OM}$ indicated very insignificant changes in the batch weight (from 0.2 to $0.8 \%$ ). In general, these values simultaneously determine the content of $\mathrm{CO}_{\text {org }}$ in samples. The low concentration of this compound in the samples of the section under consideration, as well as in the case of studying the previous areas, makes it very difficult to determine the type of OM. Due to the insufficient mass of the combustible substance, the formation and development of the morphology of the exothermic peak on the DTA curve does not reach such a level that the history of the origin of this organic compound can be reliably read. By the nature of the transition from $\mathrm{CO}_{\text {org }}$ to $\mathrm{CO}_{2}$ in the range of $250-500^{\circ} \mathrm{C}$, this substance roughly relates to the subcolloidal type of organic matter [13].

For the second section, the study of the material composition of rocks (samples K-14-1 - K-14-44) was compared with the descriptions of the thermal behavior of mineral samples set out in reference sources and accumulated in the data bank in the laboratory that conducted these studies (Table 2). Interpretation of differential thermal and thermogravimetric curves showed the presence of siliceous, feldspathic (albite, orthoclase, etc.), clayey (montmorillonite, hydromica) and carbonate (calcite, rarely dolomite) minerals with impurities in some samples of iron oxides and hydrated thermogravimetry. Among these formations, gypsum, tremolite and stilpnomelanewere found in some samples.

The following is a characteristics and physical - chemical interpretation of the state of the structures of the most typical mineral phases. Quartz, the most common mineral. When heated, it is detected in the region of $500^{\circ} \mathrm{C}$ during the polymorphic transition of its structure from the $\alpha$ state to the $\beta$ modification. In this transformation, the system leaves on the DTA-curve a low-intensity, but clearly pronounced peak of endothermic orientation. In the presence of thermal interference, provided by thermal decomposition of layered silicates in the vicinity of $\alpha-\mathrm{SiO}_{2}$ conversion temperatures, quartz was diagnosed by re-burning the sample or in the cooling mode of the system in the region of $500^{\circ} \mathrm{C}$.

Hydromica, widely distributed in the rocks of the studied section. As derivatives of micas, they are closely associated with each other and are almost always found together. Hydromica includes both forms of hydrate - molecular water $\left(\mathrm{H}_{2} \mathrm{O}\right)$ and constitutional - group $\mathrm{OH}$. The first characteristic thermal sign of the presence in the sample of this occurrence is the formation of the stage of weight loss on the thermogravimetric curve caused by the release into the atmosphere of molecular water in the low-temperature (60$200^{\circ} \mathrm{C}$ ) stage of destruction of the system. Dehydration of hydromica proceeds accompanied by an endothermic effect, which leaves a peak in the region of $120^{\circ} \mathrm{C}$ on the DTA curve.

Table 2 indicates the degree of thermal maturity of hydromica, which varies along the section from $1.25 \%$ (K-14-25-a) to $10 \%$ (K-14-1-a). A sharp drop in the content of hydromica in samples (within the profile) was noted only at the border of the selection of two samples K-14-1-a and K-14-1-b. Here the mass difference of hydromica reaches $10 \%$. The structure of illite is crystalline closest to montmorillonite. Molecular water found in the composition of clay minerals is presented in two qualities. One of them, characterized by a less strong bond with clay particles, is of a sorptive type. Usually it is adjacent to the surfaces of the particles, and is held there by forces of unbalanced electric charges, which are formed mainly in the places of brokenbonds. When the system is heated to the limits of $80-150^{\circ} \mathrm{C}$, the molecules of this water rush into the atmosphere. Other water, localized in the deeper levels of the structural structure of illite and montmorillonite, refers to interlayer water. In terms of their functional qualities and resistance to bond breaks inside the system, $\mathrm{H}_{2} \mathrm{O}$ molecules of similar belonging leave the system at higher temperatures $150-500^{\circ} \mathrm{C}$. 
International Journal of Engineering Research and Technology. ISSN 0974-3154, Volume 13, Number 5 (2020), pp. 1045-1056

(C) International Research Publication House. https://dx.doi.org/10.37624/IJERT/13.5.2020.1045-1056

Table 2. Results of thermal analysis of carbonate-terrigenous rocks - Carboniferous-Permian of the southwestern part of the ShuSarysu depression

\begin{tabular}{|c|c|c|c|c|c|c|c|c|c|c|}
\hline \multirow[t]{2}{*}{$\begin{array}{l}\text { Lithology, age, } \\
\text { № sample }\end{array}$} & \multicolumn{5}{|c|}{ Mineral composition of samples, \% } & \multicolumn{4}{|c|}{$\begin{array}{l}\text { Compounds carried from } \\
\text { minerals during their } \\
\text { heating, } \% \text { by mass }\end{array}$} & \multirow{2}{*}{ 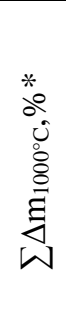 } \\
\hline & $\stackrel{N}{\stackrel{Z}{Z}}$ & 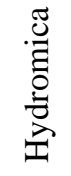 & $\frac{\mathscr{c}}{\frac{\mathscr{C}}{\pi}}$ & $\begin{array}{l}\stackrel{\mathscr{\Xi}}{\Xi} \\
\frac{0}{0} \\
\stackrel{0}{\circ}\end{array}$ & Other minerals & $0^{\circ}$ & 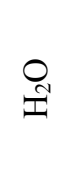 & $\overline{0}$ & ర & \\
\hline 1 & 2 & 3 & 4 & 5 & 6 & 7 & 8 & 9 & 10 & 11 \\
\hline $\begin{array}{l}\text { Conglomerate with quartz } \\
\text { and carbonate pebbles, } \\
\mathrm{C}_{1} \mathrm{v}, \mathrm{K}-14-1-\mathrm{a}\end{array}$ & $\sim 15$ & $\sim 10$ & 73.4 & - & - & 1.6 & 1.0 & 0.7 & 32.3 & 35.6 \\
\hline $\begin{array}{ll}\text { Siliceous } & \text { limestone, } \\
\mathrm{C}_{1} \mathrm{v}, \mathrm{K}-14-1-\mathrm{b} & \end{array}$ & $>15$ & - & 82.7 & - & - & 0.4 & 0.4 & - & 36.4 & 37.2 \\
\hline $\begin{array}{l}\text { Siliceouslimestone, } \mathrm{C}_{1} \mathrm{v}, \mathrm{K}- \\
14-2\end{array}$ & $<10$ & 3.8 & 87.3 & - & - & 0.4 & 0.6 & F & 38.4 & 39.4 \\
\hline $\begin{array}{l}\text { Siliceous } \quad \text { dolomitic } \\
\text { limestone, } \mathrm{C}_{1} \mathrm{v}, \mathrm{K}-14-3\end{array}$ & $\sim 10$ & 3.1 & 52.7 & 33.1 & - & 0.5 & 0.5 & - & 39.0 & 40.0 \\
\hline Limestone, $\mathrm{C}_{1} \mathrm{v}, \mathrm{K}-14-4$ & $>5$ & - & 92.1 & - & - & 0.2 & 0.7 & $F$ & 40.5 & 41.4 \\
\hline $\begin{array}{l}\text { Siliceouslimestone, } \mathrm{C}_{1} \mathrm{v}, \mathrm{K} \text { - } \\
14-5\end{array}$ & $\sim 10$ & - & 89.1 & - & - & 0.3 & 0.5 & - & 39.2 & 40.0 \\
\hline $\begin{array}{l}\text { Siliceouslimestone, } \mathrm{C}_{1} \mathrm{v}, \mathrm{K}- \\
14-6\end{array}$ & $>5$ & - & 96.1 & - & - & 0.2 & 0.7 & - & 42.3 & 43.2 \\
\hline Limestone, $\mathrm{C}_{1} \mathrm{v}, \mathrm{K}-14-7$ & $\sim 5$ & - & 94.1 & - & - & - & 0.2 & - & 41.4 & 41.6 \\
\hline $\begin{array}{l}\text { Siliceous limestone, } \mathrm{C}_{1} \mathrm{v} \text {, } \\
\mathrm{K}-14-8-\mathrm{a}\end{array}$ & $<15$ & - & 85.7 & - & - & 0.3 & 0.4 & - & 37.7 & 38.4 \\
\hline $\begin{array}{l}\text { Siliceous limestone, } \mathrm{C}_{1} \mathrm{~V} \text {, } \\
\mathrm{K}-14-8-\mathrm{b}\end{array}$ & $<10$ & - & 90.6 & - & - & - & 0.2 & - & 39.8 & 40.0 \\
\hline $\begin{array}{l}\text { Calcareous sandstone, } \mathrm{C}_{1} \mathrm{v} \text {, } \\
\mathrm{K}-14-8-\mathrm{c}\end{array}$ & $<40$ & 2.5 & 53.0 & - & TIM (albite, orthoclase) $\sim 5$ & 0.1 & 0.4 & - & 23.3 & 23.8 \\
\hline $\begin{array}{l}\text { Calcareous sandstone, } \mathrm{C}_{1} \mathrm{v} \text {, } \\
\mathrm{K}-14-8-\mathrm{d}\end{array}$ & $>45$ & 5.9 & 41.4 & - & TIM (albite, orthoclase) $\sim 5$ & 0.25 & 0.4 & 0.45 & 18.2 & 19.3 \\
\hline $\begin{array}{l}\text { Calcareous sandstone, } \mathrm{C}_{1} \mathrm{v} \text {, } \\
\mathrm{K}-14-8-\mathrm{e}\end{array}$ & $<40$ & 3.8 & 21.8 & 20.1 & TIM (albite, orthoclase) $\sim 15$ & - & 0.4 & 0.2 & 19.2 & 19.8 \\
\hline $\begin{array}{l}\text { Calcareous sandstone, } \mathrm{C}_{1} \mathrm{v} \text {, } \\
\mathrm{K}-14-8-\mathrm{f}\end{array}$ & $\sim 40$ & 4.4 & 43.8 & 5.1 & TIM (albite, orthoclase) $>5$ & 0.2 & 0.5 & 0.2 & 21.7 & 22.6 \\
\hline $\begin{array}{l}\text { Coral limestone, } \mathrm{C}_{1} \mathrm{v} \text {, } \\
\mathrm{K}-14-8-\mathrm{g}\end{array}$ & - & - & 98.2 & - & - & 0.15 & 0.25 & - & 43.2 & 43.5 \\
\hline $\begin{array}{l}\text { Dolomitic siltstone, } \mathrm{C}_{1} \mathrm{~s} \text {, } \\
\mathrm{K}-14-9\end{array}$ & $\sim 40$ & 5.9 & 3.4 & 26.8 & TIM (oxidesFe and Ca) $>20$ & $\begin{array}{l}\mathrm{C}+ \\
\mathrm{C}_{\mathrm{org}} \\
1.7\end{array}$ & 0.9 & 0.2 & 14.3 & 17.1 \\
\hline
\end{tabular}


International Journal of Engineering Research and Technology. ISSN 0974-3154, Volume 13, Number 5 (2020), pp. 1045-1056 (C) International Research Publication House. https://dx.doi.org/10.37624/IJERT/13.5.2020.1045-1056

\begin{tabular}{|c|c|c|c|c|c|c|c|c|c|c|}
\hline $\begin{array}{l}\text { Dolomite calcareous- } \\
\text { siliceous, } \mathrm{C}_{1} \mathrm{~s}, \mathrm{~K}-14-10\end{array}$ & $\sim 20$ & - & 9.3 & 64 & TIM(albite, orthoclase) $>5$ & 0.4 & 0.5 & - & 34.6 & 35.5 \\
\hline $\begin{array}{l}\text { Siliceouslimestone, } \mathrm{C}_{1} \mathrm{~S}, \\
\mathrm{~K}-14-11\end{array}$ & $<15$ & - & 67.3 & - & TIM(albite, orthoclase) $<20$ & 0.6 & 0.4 & - & 29.6 & 30.6 \\
\hline $\begin{array}{l}\text { Sandstone, } \mathrm{C}_{2-3} \\
\mathrm{~K}-14-12\end{array}$ & $\sim 50$ & - & 9.4 & - & $\begin{array}{l}\text { clinochlore }-2.2, \quad \text { TIM } \\
(\text { (albite, mica, oxidesFe) } \sim 33\end{array}$ & 0.4 & 0.55 & 0.6 & 4.15 & 5.7 \\
\hline $\begin{array}{l}\text { Conglomerate with silicate } \\
\text { pebble, } \mathrm{C}_{2-3} \text {, } \\
\mathrm{K}-14-13\end{array}$ & $\sim 40$ & - & 47.3 & - & $\begin{array}{lll}\text { clinochlore }- & 2.5, & \text { TIM } \\
(\text { mica, oxides Fe) } & <10 & \end{array}$ & 0.3 & 0.5 & 0.7 & 20.8 & 22.3 \\
\hline $\begin{array}{l}\text { Conglomerate with silicate } \\
\text { pebble, } \mathrm{C}_{2-3}, \mathrm{~K}-14-14\end{array}$ & $\sim 60$ & - & 29.9 & - & $\begin{array}{l}\text { TIM (albite, mica, oxides Fe) } \\
<10 \text {, clinochlore }-4.4\end{array}$ & 0.3 & 0.5 & 1.2 & 10.5 & 12.5 \\
\hline $\begin{array}{l}\text { Calcareoussandstone, } \\
\mathrm{C}_{2-3}, \mathrm{~K}-14-15\end{array}$ & $>40$ & - & 29.3 & - & $\begin{array}{l}\text { Clinochlore }-1.6 \quad \text { TIM } \\
(\text { albite, mica, } \\
\text { oxides Fe })<30\end{array}$ & 0.25 & 0.5 & 0.45 & 12.9 & 14.1 \\
\hline 1 & 2 & 3 & 4 & 5 & 6 & 7 & 8 & 9 & 10 & 11 \\
\hline $\begin{array}{l}\text { Siltstone, } \mathrm{C}_{2-3} \\
\mathrm{~K}-14-16\end{array}$ & $\sim 30$ & - & 0.8 & - & $\begin{array}{l}\text { montmorillonite } \\
\text { (dehydrated) }-9.1, \quad \text { TIM } \\
\text { (albite, mica, oxide Fe) } \sim 60\end{array}$ & - & 0.5 & 0.75 & 0.35 & 1.6 \\
\hline $\begin{array}{l}\text { Siltstone, } \mathrm{C}_{2-3} \\
\mathrm{~K}-14-17\end{array}$ & $\sim 40$ & - & 3.2 & - & $\begin{array}{l}\text { montmorillonite } \\
\text { (dehydrated)-12.6, } \\
\text { clinochlore-4.0, TIM (albite, } \\
\text { mica, oxide Fe) > } 45\end{array}$ & 0.3 & 1.5 & 1.8 & 1.4 & 5.0 \\
\hline  & $\sim 30$ & - & 14.4 & - & $\begin{array}{l}\text { montmorillonite } 7.4, \\
\text { clinochlore-1.1, TIM (albite, } \\
\text { mica, oxide Fe) > } 45\end{array}$ & 0.25 & 0.65 & 0.95 & 6.35 & 8.2 \\
\hline Siltstone, $\mathrm{C}_{3}, \mathrm{~K}-14-20$ & $\sim 30$ & 4.7 & - & - & $\mathrm{TIM}>50$ & 0.3 & 0.7 & 1.75 & - & 2.75 \\
\hline $\begin{array}{l}\text { Sandstone, } \mathrm{P}_{1} \text {, } \\
\mathrm{K}-14-21\end{array}$ & $\sim 30$ & 1.3 & 14.5 & - & $\begin{array}{l}\text { clinochlore- } 0.75 \text {, Kaolinite- } \\
8.0, \text { montmorillonite }-5 \text {, } \\
\text { TIM (albite, mica, oxide Fe) } \\
40\end{array}$ & 0.2 & 0.5 & 0.4 & 6.4 & 7.5 \\
\hline $\begin{array}{l}\text { Limestone, } \mathrm{P}_{1}, \\
\mathrm{~K}-14-22\end{array}$ & - & - & 70.0 & - & TIM (albite, mica, ) <30 & 0.2 & - & 0.2 & 30.8 & 31.2 \\
\hline $\begin{array}{l}\text { Limestone, } \mathrm{P}_{1}, \\
\mathrm{~K}-14-23\end{array}$ & - & 3.1 & 58.9 & - & $\begin{array}{l}\text { montmorillonite } \\
\text { (dehydrated)-15, } \\
\text { clinochlore-1.8, TIM (albite, } \\
\text { mica, })>20\end{array}$ & 0.4 & 1.0 & 3.0 & 25.9 & 30.3 \\
\hline $\begin{array}{l}\text { Sandstone, } \mathrm{P}_{1}, \\
\mathrm{~K}-14-24\end{array}$ & $\sim 30$ & 5.9 & 8.2 & - & $\begin{array}{l}\text { Tremolite }-8.0, \text { clinochlore } \\
-0.75, \text { TIM (albite, mica, })> \\
45\end{array}$ & 0.35 & 0.75 & 0.9 & 3.6 & 5.6 \\
\hline $\begin{array}{l}\text { Calcareous sandstone, } \mathrm{P}_{1} \text {, } \\
\mathrm{K}-14-25-\mathrm{a}\end{array}$ & $\sim 20$ & 1.25 & 32.6 & - & 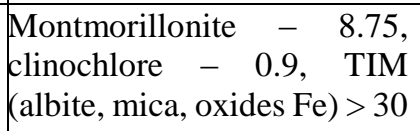 & 0.25 & 0.85 & 1.35 & 14.35 & 16.8 \\
\hline $\begin{array}{l}\text { Sandstone, } \mathrm{P}_{1} \\
\mathrm{~K}-14-25-\mathrm{b}\end{array}$ & $\sim 30$ & 1.9 & 1.1 & 1.2 & \begin{tabular}{|lll} 
montmorillonite & & \\
(dehydrated) & - & 12.8, \\
clinochlore - & 1.1, & TIM
\end{tabular} & - & 1.2 & 1.95 & 1.05 & 4.2 \\
\hline
\end{tabular}


International Journal of Engineering Research and Technology. ISSN 0974-3154, Volume 13, Number 5 (2020), pp. 1045-1056

(C) International Research Publication House. https://dx.doi.org/10.37624/IJERT/13.5.2020.1045-1056

\begin{tabular}{|c|c|c|c|c|c|c|c|c|c|c|}
\hline & & & & & $\begin{array}{l}\text { (albite, mica, oxidesFe, } \\
\text { decomposed silicates) } \sim 50\end{array}$ & & & & & \\
\hline $\begin{array}{l}\text { Limestone, } \mathrm{P}_{1} \text {, } \\
\mathrm{K}-14-26\end{array}$ & - & - & 92.3 & - & TIM(albite) $\sim 8$ & - & - & - & 40.6 & 40.6 \\
\hline $\begin{array}{l}\text { Calcareoussandstone, } \mathrm{P}_{1} \text {, } \\
\text { K-14-27 }\end{array}$ & $>20$ & 1.3 & 46.6 & - & $\begin{array}{l}\text { montmorillonite }-10.0 \text {, } \\
\text { clinochlore }-1.1, \quad \text { TIM } \\
\text { (albite, mica,decomposed } \\
\text { silicates) < } 20\end{array}$ & - & 0.4 & 2.3 & 20.5 & 23.2 \\
\hline $\begin{array}{l}\text { Gypsum mixed with sandy } \\
\text { material, } \mathrm{P}_{2} \text {, } \\
\mathrm{K}-14-28-\mathrm{b}\end{array}$ & $<10$ & - & - & - & $\begin{array}{l}\text { gypsum - 69.6, chlorite - } \\
\text { 0.4, TIM (albite, oxidesSi, } \\
\text { Al, Fe) } 18\end{array}$ & 0.5 & 14.55 & 0.1 & - & $15.4 *$ \\
\hline $\begin{array}{l}\text { Sandstone, } \mathrm{P}_{2} \text {, } \\
\mathrm{K}-14-28-\mathrm{c}\end{array}$ & $\sim 20$ & 5.0 & 12.3 & 6.8 & $\begin{array}{l}\text { gypsum }-8.9, \text { kaolinite }- \\
\text { 2.3, clinochlore }-1.3 \text {, ТIM } \\
\text { (albite, mica, oxides } \mathrm{Si}, \mathrm{Al} \text { и } \\
\mathrm{Fe}) \sim 43\end{array}$ & - & 2.45 & 0.9 & 8.65 & 12.0 \\
\hline $\begin{array}{l}\text { Gypsum mixed with sandy } \\
\text { material, } \mathrm{P}_{2}, \mathrm{~K}-14-28-\mathrm{d}\end{array}$ & $\sim 20$ & - & 3,4 & - & $\begin{array}{l}\text { gypsum }-43.1, \text { TIM (albite } \\
\text { 15, oxides } \mathrm{Al}, \mathrm{Si} \sim 18 \text { ) }\end{array}$ & 0.2 & 9.0 & - & 1.5 & $12.0 *$ \\
\hline $\begin{array}{l}\text { Sandstone, } \mathrm{P}_{2} \text {, } \\
\mathrm{K}-14-28-\mathrm{e}\end{array}$ & $\sim 40$ & 1.3 & 10.5 & - & $\begin{array}{l}\text { gypsum }-6.2, \text { kaolinite }- \\
2.3 \text {, clinochlore }-1.3, \mathrm{TIM} \\
\text { (albite } \sim 25, \text { oxides } \mathrm{Al}, \mathrm{Si}, \mathrm{Ca} \\
\text { 13) }\end{array}$ & 0.2 & 1.3 & 0.9 & 4.6 & 7.0 \\
\hline $\begin{array}{l}\text { Calcareous sandstone, } \mathrm{P}_{2}, \\
\mathrm{~K}-14-28-\mathrm{f}\end{array}$ & $\sim 70$ & - & 29.3 & - & $\mathrm{H}_{2} \mathrm{O}($ free $)-0.7$ & 0.25 & 0.75 & - & 12.9 & 13.9 \\
\hline $\begin{array}{l}\text { Tuffaceous } \\
\text { sandstone, } \mathrm{P}_{2} \\
\text { K-14-29-b }\end{array}$ & $<40$ & 8.1 & 6.3 & 0.8 & $\begin{array}{l}\text { Kaolinite }-1.9, \text { TIM: albite } \\
\text { 25, mica>5, oxides (Si, Ca } \\
\text { и } \mathrm{Mg}) \sim 12\end{array}$ & 0.4 & 1.1 & 0.7 & 3.0 & 5.2 \\
\hline 1 & 2 & 3 & 4 & 5 & 6 & 7 & 8 & 9 & 10 & 11 \\
\hline $\begin{array}{l}\text { I. CARBONIFEROUS } \\
\text { SILTSTONE , } \mathrm{P}_{2} \text {, } \\
\text { K-14-29-c }\end{array}$ & II. 1 & III. 5 & IV. 3 & 7.5 & $\begin{array}{l}\text { Montmorillonite }-8.5 \\
\text { chlorite }-1.7, \text { TIM - albite- } \\
10, \text { mica + tremolite + oxides } \\
(\mathrm{Si}, \mathrm{Ca}, \mathrm{Mg}) \sim 17\end{array}$ & 0.45 & 1.35 & 1.8 & 21.1 & 24.7 \\
\hline $\begin{array}{l}\text { Carboniferous siltstone, } \mathrm{P}_{2} \text {, } \\
\text { K-14-29-d }\end{array}$ & $<10$ & 3.8 & 45.7 & 10.9 & $\begin{array}{l}\text { montmorillonite }-5.4, \\
\text { clinochlore }-\end{array}$ & 0.5 & 1.6 & 1.1 & 25.3 & 28.5 \\
\hline $\begin{array}{l}\text { Carboniferous siltstone, } \mathrm{P}_{2} \text {, } \\
\mathrm{K}-14-29-\mathrm{e}\end{array}$ & $<10$ & 7.5 & 53.6 & 8.4 & $\begin{array}{l}\text { montmorillonite }-5.8, \\
\text { goethite }-1.3, \mathrm{TIM} \text { (albite }- \\
5, \text { oxides }(\mathrm{Si}, \mathrm{Ca}, \mathrm{Mg})-7\end{array}$ & 0.85 & 2.1 & 0.95 & 27.6 & 31.5 \\
\hline Sandstone, $\mathrm{P}_{2}, \mathrm{~K}-14-29-\mathrm{f}$ & $\sim 10$ & 3.1 & 4.9 & - & $\begin{array}{l}\text { montmorillonite }-5.0, \\
\text { goethite }-0.8, \text { TIM (albite }- \\
40, \text { oxides }(\mathrm{Si}, \mathrm{Fe}, \mathrm{Ca}) \sim 36\end{array}$ & 0.3 & 0.8 & 0.9 & 2.15 & 4.15 \\
\hline
\end{tabular}

Montmorillonite in the composition of the rocks of the studied section is not the most common mineral. In its structure, it contains two forms of water - molecular $\left(\mathrm{H}_{2} \mathrm{O}\right)$ and interlayer
$(\mathrm{OH})$, the removal of which during the decomposition of the structure causes endothermic effects of different power at different temperature ranges. According to these thermal 
criteria, the above mineral was diagnosed, and the thermogravimetry of its dehydration and high-temperature dissociation was used to calculate the amount of this formation.

Chlorite is found in the mid-Upper Carboniferous and Lower Permian rocks. Its quantity in the samples varies from $0.75 \%$ (samples K-14-21 and K-14-24) to 4.4\% (K-14-14). Within $800-850^{\circ} \mathrm{C}$, the mineral gives a weak endothermic reaction, due to the removal of the structure of hydroxyl water from the talcpyrophyllite package. In the range of $500-600^{\circ} \mathrm{C}$, a hydroxyl group is released into the atmosphere, forming a brucite layer in the chlorite structure. According to the results of the analysis of the samples, the process of the first stage of dehydration of chlorite is accompanied by the loss of part of the thermal energy of the system, which leaves a marked peak on the DTA curve at $530^{\circ} \mathrm{C}$. The intensity of this endothermic process exceeds the effect of heat generation, which is associated with the removal of the hydroxyl group from the alumisilicate layers of the system.

During dynamic heating, organic matter gives thermochemical parameters that differ in many respects from the thermal characteristics of the minerals forming together with the unified complex $\mathrm{CO}_{\text {org }}+$ inorganic compounds. The specificity of thermal decomposition of organic carbon oxide lies in the continuity of the process of carbon oxidation, no matter how long it lasts. Interrupting the reaction of the interaction of organic matter with oxygen by time or temperature during the heating period means that several oxygen-acceptor oxidation centers are present in the test system. For systems of inorganic composition, the stage character of decomposition is quite acceptable. So the destruction of the structure of many minerals is carried out even at low temperatures, and is completed at higher temperatures. Thus, the property of this compound to respond to the temperature increase in the vicinity of $200^{\circ} \mathrm{C}$ is an important diagnostic factor in determining low organic matter content in samples Error! Reference source not found.. This feature of the thermal behavior of organic matter in the atmosphere of atmospheric oxygen made it possible to control its content in the test samples even in the smallest fractions $-0.1-0.2 \%$.

The summary Table 2, the mineral composition and content of $\mathrm{CO}_{\text {org }}$, shows the concentration of OM in the sectionin column No. 8. The Table shows that in the vast majority of samples there is an organic compound. Thermogravimetric readings of the device recorded the variation of this substance in the range from $0.1 \%(\mathrm{~K}-14-8-\mathrm{b})$ to $1.6 \%(\mathrm{~K}-14-1-\mathrm{a})$. When comparing these indicators with the data of the mineral content of the corresponding samples (columns 3-7), it follows that a small (0.1-0.2\%) amount of organic carbon oxide is difficult to associate with the composition of the desired sample. Only starting from the value of $0.3 \%\left(\mathrm{CO}_{\text {org }}\right)$ is a certain dependence of the concentration of organic matter with the quality of the mineral content of the sample traced.

It should also be noted that in the studied section in the Early Carbon - Late Permian range, Table 2, there is no organic matter, although the material composition of some of them is appropriate for the formation of acceptor centers of organic matteraccumulation. K-14-1-a, K-14-3, K-14-11, K-14-29-e, $\mathrm{K}-14-29-\mathrm{e}$ rocks reserve due regard to the mechanism of organic matter communication with enclosing minerals, this group of samples thermogravimetric measurements found a noticeable amount $\mathrm{CO}_{\text {org }}(0.5-1.6 \%)$. In the conglomerate with quartz and carbonate pebbles (K-14-1-a), the greatest amount of organic matter was found $-1.6 \%$. According to thermal analysis (TA), rock is composed of calcite- $73 \%$, quartz 15\% and hydromica $10.6 \%$. Due to the peculiarities of the thermal behavior of these minerals, their thermal effects on the DTAcurve do not overlap the temperature range, where organic carbon oxide is usually destroyed. This arrangement of thermal reactions along the temperature range made it possible to visually follow the development of the exothermic transformation of $\mathrm{CO}_{\text {org }}$ to carbon dioxide. A segment of the differential curve in the interval of $180-480^{\circ} \mathrm{C}$, free from the thermal manifestations of the indicated calcite, quartz and hydromica, gives a curvature characteristic of the destruction of organic matter.

All thermochemical parameters and behavior when heated OM correspond to the classical types of natural analogue [8]. The given data concerning the thermal destruction of the analyzed product indicate the presence in the composition of the substance under study the components of the aromatic property that can be taken as signs of its belonging to the hydrocarbon type OM. Sample K-14-29-f with respect to the concentration of organic inclusions in it differs from the above group of carbon-containing samples in the presence of $0.85 \% \mathrm{CO}_{\text {org }}$ (Table 2). Dynamic heating of the indicated sample leaves a weakly pronounced exothermic effect on the DTA-curve in the interval $330-520^{\circ} \mathrm{C}$, accompanied by oxidation of organic carbon in the system to the level of $\mathrm{CO}_{2}$. As $\mathrm{CO}_{\text {org }}$ turns into carbon dioxide, the test sample loses weight to $0.85 \%$ of the initial mass. The configuration of the exothermic effect (single peak) on the DTA curve and the significant temperature of its manifestation $\left(380^{\circ} \mathrm{C}\right)$ indicate a carbonaceous source of organic matter.

The thermal behavior of sample K-14-3 in the range of 190$420^{\circ} \mathrm{C}$ is somewhat similar to the behavior of sample K-14-1a. This is evidenced by the poorly developed exothermally directed extremes on the DTA curve of the desired sample, the peaks of which are turned to temperatures of 310 and $400^{\circ} \mathrm{C}$. These are effects caused by the thermal conversion of organic carbon oxide to dioxide $\left(\mathrm{CO}_{2}\right)$. A small amount of chemical agents in the studied sample (5\%) predetermined the formation of only poorly developed peaks on the DTA curve, and on the TG and DTG lines only the formation of leveled manifestations was formed. The mineral composition of the sample under consideration, in which $52.7 \%$ Calcite, $33.1 \%$ Dolomite, $3.1 \%$ hydromica and $~ 10 \%$ quartz (Table 2) are found is quite acceptable for the formation, development and accumulation of organic matter in such an environment.

Siliceous limestone (sample K-14-11), when heated, leaves the DTA-curve at $310^{\circ} \mathrm{C}$ a very weakly marked manifestation of an exothermic orientation. This effect is due to oxidation of chemical agents, since according to thermal analysis and control determinations of X-ray diffraction analysis, no other substances were found in the sample under study that could repeat the trajectory of the desired DTA line in these temperature vicinities. This thermal manifestation is masked by a wide background of heat generation, extending along the 
temperature range from 210 to $530^{\circ} \mathrm{C}$. Such a mode of heat transfer in the system is determined by the quality of distribution of organic matter in the rock, namely, the degree of its dispersion.

Carbonaceous carbonate siltstone (K-14-29-e), according to thermal analysis, is very similar in composition to sample $\mathrm{K}$ 14-29-f, containing OM (Table 2). In both cases, organic inclusion is associated with similar sets of minerals (quartz, Calcite and Dolomite). The only exception is the absence of goethite in the desired rock and the presence in it of up to $1.3 \%$ of hydromica. Thermal oxidation of the studied sample proceeds in one stage as well, and the top of its exothermic effect coincides with the temperature maximum of organic matter $\left(380^{\circ} \mathrm{C}\right)$. The thermochemical parameters of the $\mathrm{CO}_{\text {org }}$ thermal transition in carbon dioxide indicate the carbonaceous identity of the OM considered here.

MLM in the composition of the studied rocks are represented by montmorillonites, chlorites, kaolinites, micas and their hydrated differences (Table 2). Their concentration in the samples is low. More significant content (5-15\%) gives montmorillonite. In most samples hydromica is not more than
$5 \%$. An exception is the sample $\mathrm{K}-14-1-\mathrm{a}$, which contains up to $10 \%$ of hydromica. The content of kaolinite in the studied formations, according to thermal analysis, does not exceed $2.3 \%$.

It should be noted that the control radiometric determinations of the composition of rocks (Table 3), noted higher concentrations of kaolinite in them than was observed according to thermal analysis. A similar variation in the quantitative content of the same mineral according to the results of two methodologically independent analyzes is not so much connected with the measurement technique, but rather as a factor of partial dehydration of the structure of the specified object [10]. In this regard, the actual content of the specified mineral in the samples corresponds to intermediate values, which record thermoanalytical and X-ray diffractometric measurements, i.e. the amount of kaolinite in the studied systems is somewhat higher than the data obtained by thermal analysis.

Table 3. Results of semi-quantitative X-ray phase analysis of the crystalline phases of the rocks of the southwestern part of the Shu-Sarysu depression

\begin{tabular}{|c|c|c|c|c|c|c|c|c|c|c|c|}
\hline $\begin{array}{l}\text { Lithology, age, } \\
\text { № sample }\end{array}$ & 胥 & $\cdot \stackrel{\overparen{\Xi}}{\Xi}$ & $\frac{\mathscr{2}}{\frac{\pi}{0}}$ & $\begin{array}{l}\stackrel{\mathscr{\Xi}}{\Xi} \\
\frac{0}{0} \\
0\end{array}$ & 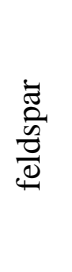 & 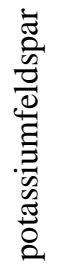 & 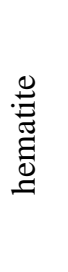 & 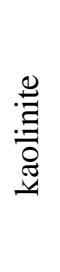 & $\frac{\stackrel{0}{0}}{\frac{0}{\frac{0}{0}}}$ & 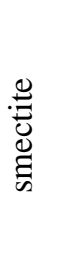 & 营 \\
\hline 1 & 2 & 3 & 4 & 5 & 6 & 7 & 8 & 9 & 10 & 11 & 12 \\
\hline $\begin{array}{l}\text { Conglomerate with quartz and } \\
\text { carbonate pebbles, } \mathrm{C}_{1} \mathrm{v}, \mathrm{K}-14-1-\mathrm{a}\end{array}$ & 27.0 & 2.6 & 70.4 & - & - & - & - & - & - & - & - \\
\hline $\begin{array}{l}\text { Siliceous limestone, } \mathrm{C}_{1} \mathrm{~V} \\
\mathrm{~K}-14-1-\mathrm{b}\end{array}$ & 21.3 & - & 78.7 & - & - & - & - & - & - & - & - \\
\hline $\begin{array}{l}\text { Siliceouslimestone, } \mathrm{C}_{1} \mathrm{v}, \\
\mathrm{K}-14-2\end{array}$ & 10.8 & 2.7 & 86.5 & - & - & - & - & - & - & - & - \\
\hline $\begin{array}{l}\text { Silicious-dolomitic limestone, } \\
\mathrm{C}_{1} \mathrm{v}, \mathrm{K}-14-3\end{array}$ & 7.0 & 2.7 & 55.2 & 35.1 & - & - & - & - & - & - & - \\
\hline Limestone, $\mathrm{C}_{1} \mathrm{v}, \mathrm{K}-14-4$ & 9.1 & - & 88.3 & - & 2.6 & & - & - & - & - & - \\
\hline $\begin{array}{l}\text { Siliceouslimestone, } \mathrm{C}_{1} \mathrm{v}, \\
\mathrm{K}-14-5\end{array}$ & 48.1 & - & 51.9 & - & - & - & - & - & - & - & - \\
\hline $\begin{array}{l}\text { Siliceouslimestone, } \mathrm{C}_{1} \mathrm{v}, \\
\mathrm{K}-14-6\end{array}$ & 4.2 & - & 95.8 & - & - & - & - & - & - & - & - \\
\hline Limestone, $\mathrm{C}_{1} \mathrm{v}, \mathrm{K}-14-7$ & 3.5 & - & 96.5 & - & - & - & - & - & - & - & - \\
\hline $\begin{array}{l}\text { Siliceous limestone, } \mathrm{C}_{1} \mathrm{v}, \\
\mathrm{K}-14-8-\mathrm{a}\end{array}$ & 14.7 & - & 78.2 & 2.4 & 1.8 & 2.9 & - & - & - & - & - \\
\hline $\begin{array}{l}\text { Siliceous limestone, } \mathrm{C}_{1} \mathrm{v}, \mathrm{K}-14-8- \\
\mathrm{b}\end{array}$ & 10.9 & - & 86.4 & - & 1.3 & 1.5 & - & - & - & - & - \\
\hline $\begin{array}{l}\text { Calcareous sandstone, } \mathrm{C}_{1} \mathrm{v}, \mathrm{K}-14- \\
8-\mathrm{c}\end{array}$ & 45.5 & 2.9 & 40.4 & 2.9 & 0.9 & 5.4 & 2.0 & - & - & - & - \\
\hline
\end{tabular}


International Journal of Engineering Research and Technology. ISSN 0974-3154, Volume 13, Number 5 (2020), pp. 1045-1056 (C) International Research Publication House. https://dx.doi.org/10.37624/IJERT/13.5.2020.1045-1056

\begin{tabular}{|c|c|c|c|c|c|c|c|c|c|c|c|}
\hline 1 & 2 & 3 & 4 & 5 & 6 & 7 & 8 & 9 & 10 & 11 & 12 \\
\hline $\begin{array}{l}\text { Calcareous sandstone, } \mathrm{C}_{1} \mathrm{v}, \mathrm{K}-14- \\
8-\mathrm{d}\end{array}$ & 46.2 & 3.8 & 32.6 & 7.1 & 1.6 & 6.8 & 1.9 & - & - & - & - \\
\hline $\begin{array}{l}\text { Calcareous sandstone, } \mathrm{C}_{1} \mathrm{v}, \mathrm{K}-14- \\
8-\mathrm{e}\end{array}$ & 42.9 & 2.5 & 23.8 & 20.7 & 1.3 & 7.3 & 1.5 & - & - & - & - \\
\hline $\begin{array}{l}\text { Calcareous sandstone, } \mathrm{C}_{1} \mathrm{v}, \\
\mathrm{K}-14-8-\mathrm{f}\end{array}$ & 37.5 & 3.2 & 43.7 & 5.5 & 2.8 & 5.4 & 1.9 & - & - & - & - \\
\hline $\begin{array}{l}\text { Corallimestone, } \mathrm{C}_{1} \mathrm{v}, \\
\mathrm{K}-14-8-\mathrm{d}\end{array}$ & 4.0 & - & 96.0 & - & - & - & - & - & - & - & - \\
\hline $\begin{array}{l}\text { Dolomitic siltstone, } \mathrm{C}_{1} \mathrm{~s} \text {, } \\
\mathrm{K}-14-9\end{array}$ & 37.7 & 4.3 & 3.3 & 45.4 & - & - & 2.7 & 6.6 & - & - & - \\
\hline $\begin{array}{l}\text { Calcareous-siliciousdolomite, } \\
\mathrm{C}_{1} \mathrm{~s} \\
\mathrm{~K}-14-10\end{array}$ & 19.0 & - & 4.4 & 71.7 & 1.7 & 3.2 & - & - & - & - & - \\
\hline $\begin{array}{l}\text { Siliceouslimestone, } \mathrm{C}_{1} \mathrm{~s}, \\
\mathrm{~K}-14-11\end{array}$ & 12.1 & - & 75.0 & - & 12.8 & - & - & - & - & - & - \\
\hline Sandstone, $\mathrm{C}_{2-3}, \mathrm{~K}-14-12$ & 57.8 & 2.7 & 10.2 & - & 24.4 & - & 1.6 & 3.3 & - & - & \\
\hline $\begin{array}{l}\text { Conglomerate silicious pebbles, } \\
\mathrm{C}_{2-3}, \mathrm{~K}-14-13\end{array}$ & 37.7 & 3.2 & 46.2 & - & 8.0 & - & 2.2 & 2.7 & - & - & \\
\hline $\begin{array}{l}\text { Conglomerate silicious pebbles, } \\
\mathrm{C}_{2-3}, \mathrm{~K}-14-14\end{array}$ & 61.6 & 3.0 & 23.4 & - & 7.4 & - & 2.1 & 2.5 & - & - & 21 \\
\hline $\begin{array}{l}\text { Calcareoussandstone, } \mathrm{C}_{2-3} \text {, } \\
\mathrm{K}-14-15\end{array}$ & 40.3 & 3.4 & 37.2 & - & 16.9 & - & 2.3 & - & - & - & 22 \\
\hline Siltstone, $\mathrm{C}_{2-3}, \mathrm{~K}-14-16$ & 24.2 & 2.6 & 3.1 & - & 25.6 & - & - & 4.4 & 40.1 & - & 23 \\
\hline Siltstone, $\mathrm{C}_{2-3}, \mathrm{~K}-14-17$ & 34.1 & 5.0 & 3.3 & - & 7.8 & - & 4.4 & 3.6 & 41.8 & - & 24 \\
\hline $\begin{array}{l}\text { Sandstone with carbonaceous } \\
\text { interlayers, } \\
\mathrm{C}_{2-3}, \mathrm{~K}-14-18\end{array}$ & 24.6 & 1.5 & 17.9 & - & 37.0 & - & 1.4 & 2.6 & 15.1 & - & 25 \\
\hline Sandstone, $\mathrm{C}_{3}, \mathrm{~K}-14-19$ & 26.6 & 5.3 & - & 5.9 & 12.3 & 5.2 & 4.2 & 6.5 & 33.9 & - & 26 \\
\hline Siltstone, $\mathrm{C}_{3}, \mathrm{~K}-14-20$ & 27.8 & 4.8 & - & - & 14.8 & 6.2 & 5.1 & 7.8 & 33.6 & - & 27 \\
\hline Sandstone, $\mathrm{P}_{1}, \mathrm{~K}-14-21$ & 29.6 & 4.4 & 15.6 & - & 35.9 & 5.7 & 3.8 & 5.0 & - & - & 28 \\
\hline Limestone, $\mathrm{P}_{1}, \mathrm{~K}-14-22$ & 3.7 & - & 68.7 & - & 18.4 & - & - & - & - & 9.1 & 29 \\
\hline Limestone, $\mathrm{P}_{1}, \mathrm{~K}-14-23$ & 9.7 & 3.8 & 44.8 & - & 9.0 & - & 4.1 & - & 28.6 & - & 30 \\
\hline Sandstone, $\mathrm{P}_{1}, \mathrm{~K}-14-24$ & 24.4 & 5.6 & 13.9 & - & 21.3 & 7.1 & 8.0 & - & - & 14.6 & 5.0 \\
\hline $\begin{array}{l}\text { Calcareous sandstone, } \mathrm{P}_{1} \text {, } \\
\mathrm{K}-14-25-\mathrm{a}\end{array}$ & 14.5 & 3.1 & 20.6 & - & 9.0 & & 4.6 & - & - & & 2.4 \\
\hline Sandstone, $\mathrm{P}_{1}, \mathrm{~K}-14-25-\mathrm{b}$ & 23.5 & 3.3 & 2.1 & 4.1 & 11.6 & 2.6 & 3.6 & - & - & & 2.1 \\
\hline Limestone, $\mathrm{P}_{1}, \mathrm{~K}-14-26$ & 2.6 & - & 89.7 & - & 5.2 & 2.4 & - & - & - & & \\
\hline $\begin{array}{l}\text { Siliceouslimestone, } \mathrm{P}_{1} \\
\mathrm{~K}-14-27\end{array}$ & 24.1 & 1.8 & 38.5 & - & 18.4 & 1.6 & - & - & - & - & 2.0 \\
\hline $\begin{array}{l}\text { Gypsum mixed with sandy } \\
\text { material, } \mathrm{P}_{2}, \mathrm{~K}-14-28-\mathrm{b}\end{array}$ & 1.8 & - & - & - & 8.1 & - & - & 89.7 & 0.5 & - & - \\
\hline Sandstone, $\mathrm{P}_{2}, \mathrm{~K}-14-28-\mathrm{c}$ & 17.0 & 2.2 & 15.8 & 9.0 & 25.9 & - & 3.0 & 24.5 & - & - & 2.6 \\
\hline $\begin{array}{l}\text { Gypsum mixed with sandy } \\
\text { material } \mathrm{P}_{2}, \mathrm{~K}-14-28-\mathrm{d}\end{array}$ & 5.1 & - & 2.4 & - & 15.5 & - & - & 77.0 & - & - & - \\
\hline Sandstone, $\mathrm{P}_{2}, \mathrm{~K}-14-28-\mathrm{f}$ & 43.0 & 4.9 & 10.8 & - & 25.2 & & - & 11.3 & - & - & 4.8 \\
\hline Calcareous sandstone, $\mathrm{P}_{2}$, & 70.5 & & 28.7 & - & & 0.7 & - & - & - & - & - \\
\hline
\end{tabular}


International Journal of Engineering Research and Technology. ISSN 0974-3154, Volume 13, Number 5 (2020), pp. 1045-1056

(C) International Research Publication House. https://dx.doi.org/10.37624/IJERT/13.5.2020.1045-1056

\begin{tabular}{|c|c|c|c|c|c|c|c|c|c|c|c|}
\hline K-14-28-f & & & & & & & & & & & \\
\hline $\begin{array}{l}\text { Carboniferous Siltstone, } \mathrm{P}_{2} \text {, } \\
\mathrm{K}-14-29-\mathrm{c}\end{array}$ & 7.2 & 2.0 & 23.6 & 2.0 & 7.4 & 1.0 & - & - & - & 3.7 & 1.1 \\
\hline $\begin{array}{l}\text { Carboniferous Siltstone, } \mathrm{P}_{2} \text {, } \\
\text { K-14-29-d }\end{array}$ & 7.0 & 2.7 & 37.8 & - & 7.2 & - & - & - & - & - & 1.4 \\
\hline 1 & 2 & 3 & 4 & 5 & 6 & 7 & 8 & 9 & 10 & 11 & 12 \\
\hline $\begin{array}{l}\text { Carboniferous Siltstone, } \mathrm{P}_{2} \text {, } \\
\text { K-14-29-e }\end{array}$ & 9.8 & & 68.7 & - & 5.0 & - & - & - & - & - & 2.4 \\
\hline Sandstone, $\mathrm{P}_{2}, \mathrm{~K}-14-29-\mathrm{f}$ & 10.3 & 1.8 & 3.9 & - & 35.1 & 4.7 & 3.2 & - & - & 11.0 & 1.0 \\
\hline
\end{tabular}

X-ray structural analysis on a semi-quantitative basis was carried out on an automated diffractometer DRON-2, on which quantitative ratios of various mineral crystalline phases were determined. The diffractograms were interpreted using ICDD data: a base of powder diffractometric data PDF2 (Powder Diffraction File) and diffractograms of impurities-free minerals. Characteristic diffraction reflexes were noted, allowing identification of the phases present. The carbonaceous sandstone and limestone carbonate layers, based on calcite, quartz, sometimes dolomite, mica and feldspar, dominate at the base of the coal mine. The rest of the (C1s) section (samples K14-5 - K-14-11), folded with limestone (samples K-14-5 samples K-14-8), calcite content reaches 96\%, and quartz $48 \%$. Calcareous sandstone (K-14-9, and -10) contain plagioclase and orthoclase impurities. The composition of sandstone in the range of samples K-14-11 - samples K-14-14 varies slightly. The main components are calcite, quartz, sometimes dolomite and orthoclase. Content of clay minerals (mica and chlorite) no more than 2-3\%. In organic Limestone (K-14-8-d), Calcite content is $96 \%$, impurity is quartz. The composition of red and gray Silts tones (sample K-14-16 - 18) is characterized by sharp fluctuations in the composition and content of components: Calcite from 3 to $75 \%$, quartz from 12 to $37 \%$, dolomite to $72 \%$. Red sandstone (age $\mathrm{C}_{3}$ ) contains an admixture of hematite. In some samples, impurities of mica, chloritea were found. The alternating silts and sandstone of Upper Permian have a complex polymineral composition (K14-29-c - 29th) with prevalence of calcite, montmorillonite and albite.

\section{CONCLUSION}

The method of localization of dispersed organic matter in the composition of quartz-feldspar formations is based on the laws of physical and ionic sorption. In this regard, the connection with the surface of the $\mathrm{SiO} 2$ crystal is carried out mainly through the underlying films of layered silicates.

The packing of organic matter in clay minerals occurs in the interstitial spaces of their layered structures or along the broken bonds of the planes of the silicon-oxygen framework of montmorillonites and members of this series of minerals.

The accumulation of Corg in limestone occurs in micropores, as well as in cracks and chips of monomineralic forms of $\mathrm{CaCO} 3$.
The background content of dispersed organic matter (DOM) in the Carboniferous-Permian section varies smoothly in the range of $0.1-0.5 \%$;

In terrigenous rocks, which include feldspars and clay minerals, the DOM content reaches $2 \%$.

The data obtained will be used in the correction of the forecast resources of the south-western part of the Shu-Sarysu basin.

\section{ACKNOWLEDGEMENT}

The work was done with the financial support of the program number BR05236800 "Solving strategic and applied problems in the oil and gas industry of Kazakhstan" according to the contract number 208 of March 19, 2018 with Committee of Science of the Ministry of Education and Science of the Republic of Kazakhstan.

\section{REFERENCES}

[1] Abdullin AA. Karatau Geology and Metallogeny. AlmaAta: Science of the Kazakh SSR, 1986. Vol. 1 Geology; Vol. 2 Metallogenyp.

[2] Atlas of lithological and paleogeographic, structural, palinspastic and geoecological maps of Central Eurasia. Almaty: YUGGEO, 2002.

[3] Votsalevsky ES, Bulekbaev ZE, Iskuzhiev BA, Kamalov SM, Korstyshevsky MN, Kuandykov BM, Kuantaev NE, Marchenko ON, Shudaev KS, Matloshinsky NG, Najmetdinov ASh, Filipev GP, Shabatin IV, Shakhabaev RS, Shudabaev KS. Directory "Oil and gas fields of Kazakhstan”. Almaty, 1999.

[4] Daukeev SZh, Abdullin AA, Bespaev KhA, Votsalevsky ES. Ministry of Energy and Mineral Resources of the Republic of Kazakhstan. Map of petroleum potential of Kazakhstan M 1: 2500000. Almaty: Institute of Geological Sciences KISatpayev MO and NAS RK, 2000.

[5] Korobkin VV, Buslov MM. Tectonics and geodynamics of the western Central Asian Fold Belt (Kazakhstan Paleozoides). Russian Geology and Geophysics. 2011;50:1585-1603. 
[6] Paragulgov TKh, Paragulgov KhKh, Fazylov EM, Shabalina LV. Torgay-Syrdarya region - the evolution of the deep structure and the problems of minerageny. News of the National Academy of Sciences of the Republic of Kazakhstan Series "Geology". Almaty. 2013;2:8-19.

[7] Cook HE, Buvtishkin VM, Gatovsky VA. Carbonate platform evolution, Upper Paleozoic, Southern Kazakhstan USSR: a surface analog for the supergiant Tengiz oil field, Western Kazakhstan. AmerAssof Petroleum Geologists Bulletin. 1991;75:1408-1409.

[8] Tulemissova ZhS, Korobkin VV. Features of the geodynamic evolution of the main oil and gas basins of Kazakhstan in the Paleozoic, Almaty. Bulletin of the Kazakh-British Technical University. 2017;4(43):5261.

[9] Ivanov VP. Thermal analysis of minerals and rocks. Leningrad, 1974.

[10] Grim RE. Clay mineralogy. New York-LondonToronto, 1953.

[11] Samatov IB, Slyusarev AP, Myltykbaeva LA, Nasirov $\mathrm{R}$. Composition and kinetics of thermal destruction of asphaltene-resin-paraffin deposits according to the results of differential thermal analysis. University of Astrakhan: Scientific and technical journal Geology, Geography and Global Energy. 2008;2(29):6-9.

[12] Klubova T, Korolev Yu, Roznikova A. Porous space and organic matter of collectors and tires. Moscow: Academy of Sciences of the USSR, 1986.

[13] Samatov IB, Slyusarev AP, Sultangaliev GO, Nasirov R. Determination of kaolinite in sedimentary oil rocks of the Caspian region using ESR spectroscopy, X-ray diffraction and thermal analysis. University of Astrakhan: Scientific and technical journal Geology, Geography and Global Energy. 2009;3(34):100-104. 